\title{
Perlindungan Hukum Bagi Konsumen Nasabah Dalam Card Skimming (Studi Kasus Bank Bni Syariah Pusat Di Jakarta)
}

\author{
Nevita Sari*
}

\begin{abstract}
Asbtrak
Card Skimming adalah aktivitas menggandakan informasi yang terdapat dalam pita magnetik (magnetic stripe) yang terdapat pada kartu kredit maupun ATM/Debet secara ilegal. Permasalahan yang akan dibahas dalam penelitian ini adalah Bagaimana Perlindungan Hukum Bagi Konsumen Nasabah Dalam Card Skimming (Studi Kasus Bank BNI Syariah Pusat Di Jakarta) ?. Untuk membahas permasalahan tersebut menggunakan metode penelitian normatif. Untuk mendapatkan data, penulis melakukan wawancara dengan pihak yang terkait yaitu Bank BNI Syariah Pusat di Jakarta. Penulisan ini bertujuan untuk mengetahui perlindungan hukum bagi konsumen nasabah dalam kasus Card Skimming dilihat dari Undang-Undang Nomor 8 Tahun 1999 tentang Perlindungan Konsumen, mengetahui penerapan pelaksanaan pertanggungjawaban Bank BNI Syariah Pusat di Jakarta kepada nasabah yang terkena kasus Card Skimming apakah sudah sesuai dengan Undang-Undang Perlindungan Konsumen dan mengetahui faktor-faktor yang mempengaruhi perlindungan konsumen nasabah dalam kasus card skimming. Dapat disimpulkan bahwa pihak BNI Syariah harus mengembalikan atau bertanggungjawab atas kerugian yang dialami nasabahnya dengan mengembalikan dana nasabah sebesar $100 \%$ dari kerugian yang dialami oleh nasabah Y sebelum batas waktu yang telah ditentukan pada Pasal 19 Undang-Undang Perlindungan Konsumen bahwa tanggung jawab pelaku usaha dimana pelaku usaha dalam hal ini adalah BNI Syariah harus bertanggung jawab dalam kasus skimming yang dialami oleh nasabahnya. Pemberian ganti rugi berupa uang sesuai dengan ketentuan perundang-undangan yang berlaku dan dilaksanakan dalam tenggang waktu 7 (tujuh) hari setelah tanggal transaksi.
\end{abstract}

Kata kunci : Perlindungan Konsumen, Card Skimming, Nasabah.

\section{Legal Protection For Customers Consumers In A Card Skimming (Case Study Bank Bni Syariah Center In Jakarta)}

\begin{abstract}
Card Skimming is the activity of duplicating information contained in a magnetic stripe (magnetic stripe) contained on a credit card or ATM / Debit illegally. The problem to be discussed in this research is How is Legal Protection for Consumer Customers in Card Skimming (Case Study of BNI Syariah Bank Center in Jakarta)? To discuss these problems using normative research methods. To obtain data, the authors conducted interviews with related parties, namely BNI Syariah Central Bank in
\end{abstract}

*E-mail : nevi_tasari@yahoo.co.id 
Jakarta. This writing aims to determine the legal protection for customer customers in the case of Card Skimming seen from Act Number 8 of 1999 concerning Consumer Protection, knowing the implementation of the implementation of the responsibility of the BNI Syariah Central Bank in Jakarta to customers affected by the Card Skimming case whether it is in accordance with the Act Consumer Protection Act and know the factors that influence customer customer protection in the case of card skimming. It can be concluded that BNI Syariah must return or be responsible for losses suffered by its customers by returning customer funds of $100 \%$ of losses suffered by customer Y before the deadline specified in Article 19 of the Consumer Protection Act that the responsibility of business actors in which the perpetrators business in this case is BNI Syariah must be responsible in the case of skimming experienced by its customers. Giving compensation in the form of money in accordance with the provisions of the applicable legislation and carried out within a grace period of 7 (seven) days after the date of the transaction.

Keywords: Consumer Protection, Card Skimming, Customer.

\section{Pendahuluan}

Perlindungan hukum bagi nasabah selaku konsumen dibidang perbankan menjadi sangat urgen hal ini karena adanya perjanjian antara pihak bank dan nasabah yang dibuat berdasarkan kesepakatan bank sedangkan nasabah tidak mempunyai pilihan lain, menerima atau menolak perjanjian yang diberikan oleh pihak bank. Perjanjian yang dibuat antara bank dan nasabah membuat nasabah tidak berdaya, ketika suatu kasus dialami oleh nasabah yang merugikan nasabah, sedangkan pelaku usaha yaitu bank tidak bertanggungjawab atas kasus yang dialami oleh nasabah walaupun kesalahan tidak dilakukan oleh nasabah.

Bank adalah salah satu lembaga keuangan yang mempunyai peran sangat besar dalam perekonomian suatu negara. Peranan bank sebagai penyimpan dana dan penyalur dana sangat dirasakan manfaatnya oleh masyarakat serta dunia usaha. Kenyamanan dan kecepatan bertransaksi saat ini adalah kata kunci Bank dalam memberikan layanan kepada nasabah. Layanan perbankan yang diselenggarakan kini menawarkan berbagai kemudahan yang dapat dimanfaatkan masyarakat setiap saat dan dimana saja, tidak dibatasi jarak, ruang dan waktu. Penggunaan teknologi dengan sistem online yang disediakan oleh bank mempermudah nasabah untuk melakukan transaksi perbankan tanpa harus pergi ke cabang bank. 
Beberapa jenis layanan menggunakan teknologi informasi yang sudah tidak asing lagi kita gunakan, antara lain adalah layanan perbankan online, layanan jaringan mesin ATM (Automated Teller Machine), layanan jaringan EDC (Electronic Data Capture), layanan phone banking, layanan internet banking, layanan kartu kredit, kartu cicilan dan untuk pembayaran tunda sejenisnya.

Layanan perbankan online yang sering digunakan oleh nasabah adalah ATM. Hal ini dikarenakan kemudahan yang didapat dalam menggunakan ATM yaitu kemudahan penggunaan jasa perbankan, keleluasaan waktu pelayanan, kecepatan dan ketepatan pelayanan, keamanan pelayanan dan keanekaragaman jenis pelayanan. Selain itu nasabah dapat melakukan aktivitas perbankan dengan cepat dan mudah tanpa harus mendatangi kantor cabang seperti informasi saldo, pembayaran umum seperti tagihan telepon, kartu kredit, listrik, air handphone dan uang kuliah, pembelian tiket penerbangan, isi pulsa, pemindah bukuan (open transfer), pengubahan PIN.

Pada umumnya ada dua masalah yang sering dikeluhkan konsumen jasa perbankan. Pertama, pengaduan tentang produk perbankan, seperti ATM, Kartu Kredit, dan aneka ragam jenis tabungan, termasuk keluhan produk perbankan terkait dengan janji hadiah dan iklan produk perbankan. Kedua, pengaduan tentang cara kerja petugas yang tidak simpatik dan kurang profesional khususnya petugas service point, seperti teller, customer service, dan satpam (Sudaryatmo: 1999:19-20) Dalam penulisan ini penulis akan membahas tentang kerugian nasabah yang diakibatkan karena pengambilan data nasabah yang terdapat dalam ATM/Debet.

Pada tahun 2010, berbagai media baik cetak maupun elektronik memberitakan telah terjadi fraud pada industri Kartu ATM/Debet. Sebagian besar fraud tersebut terjadi dengan menggunakan metode skimming, yaitu dengan mencuri data nasabah yang tersimpan dalam kartu. Dari kejadian ini, selain diperlukan peningkatan keamanan dalam penyelenggaraan kartu ATM/Debet yang harus dilakukan oleh para penerbit Kartu/Debet, tentunya diperlukan pula sikap kehati-hatian masyarakat sebagai pengguna dalam melakukan transaksi keuangan dengan menggunakan kartu ATM/Debet. 
Kasus skimming paling mudah kita temui saat sekarang ini, hal ini dikarenakan mudahnya transaksi elektronik mengunakan media yang digunakan untuk transaksi berupa kartu, baik kartu ATM /Debet maupun Kartu Kredit. Seperti data yang ditampilkan pada sebuah situs Adhi Maulana yang beralamat di http://money.howstuffworks.comatm-skimming.htm bahwa pada tahun 2008 silam jumlah kerugian yang ditimbulkan dari kejahatan yang berkaitan dengan kartu ATM saja di seluruh dunia mencapai 1 milliar dollar AS atau setara dengan 9 triliun rupiah (9.000 miliar rupiah) jika kurs yang dipakai adalah Rp.9.000,00 per dollar AS. Laman Bank Tech menerangkan bahwa teknik pembobolan karu ATM Nasabah melalui teknik skimming pertama kali teridentifikasi pada 2009 lalu di ATM Citibank, Woodland Hills, California. Saat itu diketahui jika teknik skimming dilakukan dengan cara mengggunakan alat yang ditempelkan pada slot mesin ATM (tempat memasukkan kartu ATM) dengan alat yang dikenal dengan nama skimmer. Modus operasinya adalah mengkloning data dari magnetic srtripe yang terdapat pada kartu ATM milik Nasabah (Adhi Maulana, Liputan6.com: 2014) Pada tahun 2010, berbagai media baik cetak maupun elektronik memberitakan telah terjadi fraud pada kartu ATM/Debet. Sebagian besar fraud tersebut terjadi dengan menggunakan metode skimming, yaitu dengan mencuri data Nasabah yang tersimpan dalam kartu. Dari kejadian ini, selain diperlukan peningkatan keamanan dalam penyelenggaraan Kartu ATM/Debet yang harus dilakukan oleh para penerbit Kartu/Debet, tentunya diperlukan pula sikap kehati-hatian masyarakat sebagai pengguna dalam melakukan transaksi keuangan dengan menggunakan kartu ATM/Debet.

Perlindungan hukum sudah tercantum didalam Undang-Undang Dasar Negara Republik Indonesia Tahun 1945 (Undang-Undang Dasar 1945) terdapat dalam alinea ke 4 Pembukaan Undang-Undang Dasar 1945 yang berbunyi "Melindungi segenap bangsa dan seluruh tumpah darah Indonesia". Secara teoritik bunyi alenia ke empat ini telah menyatakan suatu teori perlindungan hukum bagi segenap bangsa Indonesia termasuk perlindungan hak konsumen serta termasuk didalamnya perlindungan terhadap nasabah bank. 
Selain itu untuk melaksanakan perlindungan terhadap konsumen dikuatkan dengan adanya Undang-Undang No. 8 Tahun 1999 tentang Perlindungan Konsumen. Dalam Undang-Undang Perlindungan Konsumen juga dijelaskan mengenai tanggung jawab pelaku usaha yang diatur untuk memberikan kepastian hukum serta melindungi hak-hak konsumen. Dengan lahirnya Undang-Undang Perlindungan Konsumen ini diharapkan menjadi dasar serta payung hukum yang pasti dan tidak menutup kemungkinan terbentuknya peraturan-peraturan atau perundang-undangan lain dalam melindungi konsumen.

Ketidakberdayaan konsumen dalam menghadapi produsen jelas sangat merugikan kepentingan konsumen. Pada umumnya produsen berlindung di balik standard contract atau perjanjian baku yang telah ditandatangani oleh kedua belah pihak, yakni antara konsumen dan produsen ataupun melalui informasi semu yang diberikan oleh produsen kepada konsumen. Timbulnya kesadaran konsumen telah melahirkan satu cabang ilmu hukum, yaitu hukum perlindungan konsumen.

Undang-Undang Perlindungan Konsumen Nomor 8 Tahun 1999 merupakan jaminan yang seharusnya didapatkan oleh para konsumen atas setiap produk yang dibeli atau dipergunakan oleh konsumen dari produsen atau pelaku usaha. Dalam hal ini konsumen menggunakan produk yang disediakan oleh pelaku usaha berupa mesin ATM. Seringkali dalam proses pelaksaaannya UndangUndang Perlindungan Konsumen Nomor 8 Tahun 1999 masih belum maksimal dipergunakan dan terkadang tidak sesuai dengan kenyataannya.

Nasabah perbankan dalam hal ini dapat dikategorikan sebagai konsumen karena dalam Pasal 1 Undang-Undang Perlindungan Konsumen Nomor 8 Tahun 1999 yang dikatakan sebagai "konsumen adalah setiap orang pemakai barang dan/atau jasa yang tersedia dalam masyarakat, ...". Sedangkan perbankan dianggap sebagai pelaku usaha karena perbankan adalah badan usaha yang menyelenggarakan kegiatan usahanya dalam bidang ekonomi.

Minimnya pengetahuan dan kesadaran masyarakat dijadikan lahan bagi pelaku usaha yang tidak mempunyai itikad baik dalam bertransaksi untuk 
mencari keuntungan sebesar-besarnya dengan memanfaatkan seefisien mungkin sumber daya (Husni Syazali \& Heni Sri Ismiyati, 2000: 28).

Semakin banyaknya kasus skimming yang terjadi membuat penulis tertarik untuk membuat penulisan ini dengan harapan bagi pembaca dapat mengetahui cara mencegah terjadinya pencurian data melalui mesin ATM. Serta mengembalikan kepercayaan nasabah terhadap bank.

Berdasarkan uraian diatas, penulis tertarik untuk melakukan analisis tentang card skimming ATM dan bagaimana pertanggungjawaban pelaku usaha yakni bank bertanggungjawab terhadap nasabahnya yang terkena skimming tersebut serta apakah pertanggungjawaban pelaku usaha tersebut sudah sesuai dengan Undang-Undang Perlindungan Konsumen Nomor 8 Tahun 1999. Penulis juga menemukan beberapa permasalahan yang penulis kaji, yakni diantaranya :

a. Apakah penerapan pelaksanaan pertanggungjawaban Bank BNI Syariah Pusat di Jakarta kepada nasabah yang terkena kasus card skimming sudah sesuai dengan Undang-Undang Nomor 8 Tahun 1999 Tentang Perlindungan Konsumen?

b. Faktor-faktor apakah yang mempengaruhi perlindungan konsumen nasabah dalam kasus card skimming?

\section{Pembahasan}

\section{A. Pertanggungjawaban Bank BNI Syariah Terhadap Kerugian Nasabah Yang disebabkan Card Skimming}

Seorang nasabah yang berinisial Y adalah nasabah BNI Syariah Cabang Depok dengan berjenis kelamin wanita. Pada Bulan Maret 2017, nasabah tersebut melaporkan bahwa dia kehilangan uangnya yang disimpan di bank. Ketika nasabah tersebut mengambil uangnya lewat ATM, nasabah tersebut mengetahui bahwa uangnya sudah berkurang sebesar Rp. 21.000.000,00. Nasabah tersebut merasa belum mengambil uangnya lewat ATM sampai saat nasabah tersebut mengetahui uangnya hilang,

Setelah mengetahui bahwa uangnya hilang, nasabah tersebut mengadukan kasus yang dialaminya kepada BNI Syariah cabang Depok. Nasabah harus 
mengisi form pengaduan yang ada di BNI Syariah di Cabang Depok dan melengkapi syarat-syarat laporan kehilangan. Setelah lengkap persyaratannya, Nasabah menyerahkannya kepada BNI Syariah Cabang Depok, kemudian diteruskan kepada BNI Syariah Pusat. Laporan yang diajukan oleh nasabah Y segera ditindaklanjuti dengan pengecekan di sistem ternyata benar terjadi penarikan didaerah yang berbeda dari daerah tempat tinggal nasabah pada saat yang hampir bersamaan yaitu di Tangerang, Bekasi, Bandung, Sukabumi selama 3 hari. Pelaku skimmer melakukan aksi penarikan dana di ATM ditempat yang berbeda dengan domisili pemilik ATM. Hal ini dimaksudkan untuk menghilangkan jejak mereka agar tidak diketahui.

Hasil Analisa dari pihak BNI Syariah menunjukkan adanya ketidakwajaran dalam penarikan dana tersebut, untuk memperkuat analisatersebut maka pihak BNI Syariah melihat dari CCTV yang ada di ATM tempat dimana pelaku skimmer mengambil dana yaitu di daerah Tangerang, Bekasi, Bandung dan Sukabumi. Dari hasil pengecekan CCTV ternyata diketahui pelaku skimming berjenis kelamin laki-laki dan pada saat yang sama, pada jam, tanggal dan mesin ATM yang sama nasabah dari BNI Konvensional juga ada yang terkena skimming. Jadi pelaku skimming tersebut melakukan beberapa transaksi dengan ATM palsu yang berbeda di mesin ATM yang sama.

Setelah mengetahui bahwa nasabah terkena kasus skimming, maka pihak BNI Syariah bertanggung jawab atas kerugian yang dialami nasabahnya dengan mengembalikan dana nasabah sebesar $100 \%$ dari kerugian yang dialami nasabah Y yaitu sebesar Rp. 21.000.000,00.

\section{B. Pertanggungjawaban Bank Berdasarkan Akta Perjanjian BNI Syariah Dengan Nasabah Y}

Fokus persoalan perlindungan nasabah tertuju pada ketentuan peraturan perundangundangan serta ketentuan perjanjian yang mengatur hubungan antara bank dengan para nasabahnya. Hubungan hukum yang terjadi antara bank dengan nasabah dapat terwujud dari suatu perjanjian, baik perjanjian yang berbentuk akta di bawah tangan maupun dalam bentuk otentik. Dalam konteks 
inilah perlu pengamatan yang baik untuk menjaga suatu bentuk perlindungan bagi konsumen namun tidak melemahkan kedudukan posisi bank. Hal demikian perlu mengingat seringnya perjanjian yang dilakukan antara bank dengan nasabah telah dibekukan dengan sebuah perjanjian baku.

Perjanjian penggunaan ATM yang berlaku antara nasabah dengan bank BNI Syariah terdapat dalam Ketentuan Umum dan Persyaratan Pembukaan Rekening huruf D tentang Fasilitas Transaksi Perbankan Melalui Sarana Elektronik (electronic channel) yaitu:

1. Bank menyediakan fasilitas bagi nasabah untuk dapat melakukan transaksi perbankan melalui sarana elektronik (electronic channel), yaitu diantaranya adalah ATM dan derivatifnya (ATM Non Tunai, ATM Setoran Tunai) adalah fasilitas transaki perbankan 24 (dua puluh empat) jam melalui mesin ATM (Anjungan Tunai Mandiri).

2. Jenis rekening yag dapat diberikan fasilitas electronic channel ditetapkan oleh bank.

3. Untuk dapat menggunakan fasilitas electronic channel, nasabah harus memiliki tanda pengguna dan nomor identifikasi pribadi fasilitas electronic banking, yaitu untuk ATM berupa Hasanah Debit Card dan PIN (Personal Identification Number) yang digunakan untuk melakukan transaksi perbankan melalui mesin ATM, baik melalui jaringan ATM BNI, jaringan ATM Bersama, jaringan ATM Prima, jaringan ATM Cirrus dan jaringan ATM lainnya yang ditentukan oleh bank. Hasanah Debit Card juga dapat digunakan untuk pembayaran tyransaksi belanja pada merchant yang memasang logo MasterCard atau merchant lainnya yang ditentukan oleh bank.

4. Persyaratan dan tata cara pendaftaran serta pengaktifan fasilitas electronic channel ditetapkan oleh bank sesuai dengan jenis fasilitas electronic channel.

5. Tanda pengguna dan nomor identifikasi pribadi fasilitas electronic channel merupakan alat otoritas dan verifikasi bagi bank untuk melaksanakan 
transaksi yang diinstruksikan oleh nasabah melalui fasilitas electronic channel.

6. Instruksi yang disampaikan oleh nasabah melalui tanda pengguna dan nomor identifikasi pribadi fasilitas electronic channel mempunyai kekuatan hukum yang sama dengan perintah tertulis yang ditandatangai oleh nasabah.

7. Tanda pengguna dan nomor identifikasi pribadi fasilitas electronic channel hanya diketahui dan menjadi rahasia pribadi nasabah. Setiap penyalahgunaan tanda pengguna dan nomor identifikasi pribadi fasilitas electronic channel menjadi tanggungjawab risiko nasabah sepenuhnya serta membebaskan bank dari segala tuntutan akibat penyalahgunaan tersebut.

8. Semua transaksi yang dilakukan melalui fasilitas electronic channel akan mendebet dan tercatat pada rekening yang terdaftar pada fasilitas electronic channel.

9. Bank tidak berkewajiban melaksanakan instruksi dari nasabah nasabah jika saldo di rekening nasabah tidak mencukupi.

10. Dokumen berupa catatan-catatan transaksi, surat-surat, serta dokumendokumen lain yang disimpan dan dipelihara oleh bank secara tertulis diatas kertas atau media lain maupun rekaman yang dapat dilihat, dibaca ataupun didengar merupakan alat bukti yang sah dan lengkap atas transaksi yang dilaksanakan nasabah melalui fasilitas electronic channel.

11. Jenis transaksi perbankan yang dapat dilakukan melalui fasilitas electronic channel ditentukan oleh bank dan akan diberitahukan kepada nasabah dari waktu ke waktu dengan sarana yang ditentukan oleh bank.

12. Setiap transaksi melalui fasilitas electronic channel dibatasi nominal dan frekuensinya dengan suatu nominal dan frekuensi maksimum per hari yang ditentukan oleh bank atau karena sebab lain yang ditentukan oleh bank.

13. Untuk setiap transaksi yang dilakukan melalui fasilitas electronic channel, nasabah akan dibebankan biaya dan tarif sesuai dengan ketentuan yang berlaku di bank.

14. Bank sewaktu-waktu dan/atau setiap saat berhak menghentikan setiap fasilitas electronic channel yang diperoleh nasabah, jika nasabah tidak 
memenuhi/melanggar ketentuan/kebijakan yang telah ditetapkan oleh bank dan atau perundang-undangan yang berlaku, dan bank akan menginformasikan penghentian tersebut kepada nasabah dalm bentuk dan sarana apa pun.

Dari ketentuan yang dibuat oleh Bank BNI Syariah maka terlihat bahwa nasabah sebagai konsumen harus mengikuti ketentuan-ketentuan yang dibuat oleh BNI Syariah. Pada ketentuan "Tanda pengguna dan nomor identifikasi pribadi fasilitas electronic channel hanya diketahui dan menjadi rahasia pribadi nasabah. Setiap penyalahgunaan tanda pengguna dan nomor identifikasi pribadi fasilitas electronic channel menjadi tanggungjawab risiko nasabah sepenuhnya serta membebaskan bank dari segala tuntutan akibat penyalahgunaan tersebut." sangat merugikan bagi nasabah jika fasilitas electronic channel dalam hal ini Hasanah Debit Card (kartu ATM) dan PIN (Personal Identification Number) digunakan untuk melakukan transaksi perbankan melalui mesin ATM yang nasabah miliki diambil datanya secara diam-diam oleh orang lain, kemudian digandakan dan dipergunakan untuk mengambil hak nasabah tersebut. Dalam hal ini kasus yang dialami oleh nasabah bukan karena kesalahannya sedangkan dalam ketentuan tersebut bank menyatakan tidak bertanggungjawab atas kerugian yang dialami oleh nasabah.

Dalam kasus ini nasabah membutuhkan suatu perangkat hukum yang melindungi hak-hak nasabah sebagai konsumen. Kasus skimming yang dialami oleh nasabah bukan kesalahan nasabah ataupun kesalahan dari pihak bank. Oleh karena itu nasabah tidak bisa begitu saja dibebankan tanggungjawab atas kesalahan yang tidak dilakukannya. Bank sebagai pelaku usaha tidak boleh lepas dari tanggungjawab. Oleh karena itu terbentuknya Undang-Undang Perlindungan Konsumen sangat penting bagi konsumen agar mendapatkan pelayanan jasa yang nyaman, aman dan selamat dalam mengkonsumsi barang dan/atau jasa. Jika bank tidak bertanggungjawab atas kerugian yang dialami oleh nasabahnya maka kepercayaan yang diberikan oleh nasabah kepada bank akan hilang dan akan berdampak buruk bagi pertumbuhan usaha bank tersebut. 


\section{Pertanggungjawaban BNI Syariah Ditinjau dari Undang-Undang Nomor 8 Tahun 1999 Tentang Perlindungan Konsumen}

Menurut Satjipto Raharjo (2003 : 121). Perlindungan hukum adalah memberikan pengayoman terhadap hak asasi manusia (HAM) yang dirugikan orang lain dan perlindungan itu diberikan kepada masyarakat agar dapat menikmati semua hak-hak yang diberikan oleh hukum.

Perlindungan hukum terhadap nasabah tidak dapat dipisahkan dengan Undang-Undang Nomor 8 Tahun 1999 Tentang Perlindungan Konsumen. Dalam Pasal 1 angka 2 menyebutkan tentang pengertian konsumen yaitu setiap orang pemakai barang dan/atau jasa yang tersedia dalam masyarakat, baik bagi kepentingan diri sendiri, keluarga, orang lain maupun makhluk hidup lain, dan tidak untuk diperdagangkan”. Dari pengertian tersebut dapat diketahui bahwa nasabah bank juga termasuk sebagai konsumen karena nasabah sebagai pemakai barang dalam hal ini yaitu kartu ATM dan Mesin ATM yang diterbitkan oleh bank sebagai pelaku usaha.

Dalam Undang-Undang Nomor 8 Tahun 1999 Tentang Perlindungan Konsumen dinyatakan bahwa nasabah sebagai konsumen wajib mendapatkan pelayanan jasa yang nyaman, aman dan selamat dalam mengkonsumsi barang dan/atau jasa yang diatur dalam Pasal 4 Undang-Undang Nomor 8 Tahun 1999 Tentang Perlindungan Konsumen. Akan tetapi dalam prakteknya masih dijumpai pelaku usaha yang tidak beritikad baik kepada konsumennya yaitu memanfaatkan kelemahan konsumen akan pengetahuan serta kesadaran konsumen demi meningkatkan keuntungan yang sebesar-besarnya.

Dalam klausula perjanjian baku, bank sebagai pihak yang memiliki posisi tawar lebih tinggi dapat menentukan klausula-klausula perjanjian sehingga menjadi lebih menguntungkan bagi pihak bank. Hal ini sangat berbeda dengan perjanjian pada umumnya yang memberikan posisi tawar seimbang bagi kedua belah pihak. Dengan adanya ketidakseimbangan tersebut, pemerintah mencoba memberikan solusi melalui intervensi terhadap praktek perjanjian berdasarkan kebebasan berkontrak dengan mengatur mengenai ketentuan klausula baku. 
Dalam Ketentuan Umum dan Persyaratan Pembukaan Rekening pada BNI Syariah terdapat ketentuan yang menyebutkan bahwa "Tanda pengguna dan nomor identifikasi pribadi fasilitas electronic channel hanya diketahui dan menjadi rahasia pribadi nasabah. Setiap penyalahgunaan tanda pengguna dan nomor identifikasi pribadi fasilitas electronic channel menjadi tanggungjawab risiko nasabah sepenuhnya serta membebaskan bank dari segala tuntutan akibat penyalahgunaan tersebut." sedangkan pada Pasal 18 ayat 1 (a) Undang-Undang Nomor 8 Tahun 1999 Tentang Perlindungan Konsumen menyatakan bahwa "Pelaku usaha dalam menawarkan barang dan/atau jasa yang ditujukan untuk diperdagangkan dilarang membuat atau mencantumkan klausula baku pada setiap dokumen dan/atau perjanjian apabila isinya pengalihan tangggung jawab pelaku usaha”. Klausula yang dibuat oleh BNI Syariah tersebut merupakan klausula yang menyatakan pembebasan tanggungjawab pelaku usaha dan membebankan tanggungjawab tersebut kepada konsumen (klausula eksonerasi).

Klausula tersebut sangat bertentangan dengan Pasal 18 ayat 1 (a) UndangUndang Perlindungan Konsumen. Dengan adanya Pasal 18 ayat 1 (a) tersebut maka ketentuan yang dibuat oleh BNI Syariah dinyatakan tidak berlaku. Hal ini berarti BNI syariah harus mengikuti peraturan perundang-undangan yang berlaku di Indonesia dan harus mengganti atas kerugian yang dialami oleh nasabah Y.

Sesuai dengan Pasal 19 ayat 1 Undang-Undang Nomor 8 Tahun 1999 Tentang Perlindungan Konsumen maka BNI Syariah harus bertanggungjawab terhadap kasus card skimming yang dialami oleh nasabahnya serta harus memberikan ganti rugi atas hilangnya dana yang dimiliki oleh nasabah. Mengenai bentuk ganti ruginya diatur dalam ayat selanjutnya yang menyatakan bahwa ganti kerugian dapat berupa pengembalian uang atau penggantian barang dan/atau jasa yang sejenis atau setara nilainya.

Dalam Pasal 28 Undang-Undang Nomor 8 Tahun 1999 Tentang Perlindungan Konsumen diatur mengenai pembuktian terhadap ada atau tidaknya unsur kesalahan dalam gugatan ganti rugi sebagaimana dimaksud 
dalam Pasal 19, Pasal 22, dan Pasal 23 merupakan beban dan tanggung jawab pelaku usaha. Dalam hal ini pelaku usaha yang harus membuktikan kebenaran tentang kasus yang dialami oleh nasabahnya dengan cara memeriksa rekening nasabah Y yang terkena skimming dan melihat CCTV yang berada di mesin ATM dilokasi skimmer mengambil uang nasabah yaitu di Tangerang, Bekasi, Bandung, Sukabumi.

Setelah diselidiki maka terbukti bahwa nasabah Y kehilangan uangnya sejumlah Rp. 21.000.000,00 (dua puluh satu juta rupiah) yang telah diambil oleh pelaku skimmer. Kemudian BNI Syariah harus mengembalikan kerugian yang dialami oleh nasabahnya sebelum batas waktu yang telah ditentukan pada Pasal 19 ayat (3) Undang-Undang Perlindungan Konsumen

Jika BNI Syariah menolak dan/atau tidak memberi tanggapan atas tuntutan nasabah maka nasabah dapat menggugat melalui badan penyelesaian sengketa konsumen atau mengajukan ke badan peradilan di tempat kedudukan nasabah hal ini diatur dalam Pasal 23 Undang-Undang Perlindungan Konsumen.

\section{Faktor-faktor Yang Mempengaruhi Perlindungan Hukum Terhadap Nasabah Sebagai Konsumen}

Az. Nasution (2002: 37), membedakan definisi antara hukum konsumen dan hukum perlindungan konsumen, yakni sebagai berikut: Hukum Konsumen adalah keseluruhan asas-asas dan kaidah-kaidah yang mengatur hubungan dan masalah penyediaan dan penggunaan produk (barang dan/atau jasa) antara penyedia dan penggunanya, dalam kehidupan masyarakat. Hukum perlindungan konsumen adalah keseluruhan asas-asas dan kaidah-kaidah yang mengatur dan melindungi konsumen dalam hubungan dan masalah penyediaan dan penggunaan produk (barang dan/atau jasa) konsumen antara penyedia dan penggunanya dalam kehidupan bermasyarakat.

Berdasarkan penelitian yang dilakukan penulis terhadap nasabah yang terkena kasus card skimming maka terdapat beberapa faktor yang mempengaruhi perlindungan terhadap nasabah bank sebagai pengguna ATM yang terkena skimming yaitu: 
1. Faktor-faktor yang mempengaruhi perlindungan hukum dilihat dari Kasusnya

Berdasarkan kajian yang dilakukan Indonesia Security Incident Response Team on Internet and Infrastructure/Coordination Center (IdSIRTII/CC) Ronald Waas, ada beberapa titik rawan dalam keamanan dan kasus kejahatan terkait layanan perbankan elektronik di Indonesia (Eben Ezer Sjadari: jaringnews.com: 2012) Pertama, kerawanan prosedur perbankan, yaitu lemahnya proses identifikasi dan validasi calon nasabah, sehingga mudah untuk dilakukan pemalsuan identitas. Kedua, Kerawanan fisik, dimana kartu ATM yang digunakan bank saat ini jenisnya magnetic stripe card yang tidak dilengkapi pengaman chip (smart card), sehingga skimming PIN mudah dilakukan. Ketiga, kerawanan aplikasi, aplikasi yang dikembangkan oleh perbankan harus mengikuti faedah secure programming dari front end sampai dengan back end. Keempat, Kerawanan perilaku menyangkut faktor manusia baik dari sisi perbankan maupun dari sisi nasabah yang cenderung ceroboh dalam bertransaksi. Kelima, Kerawanan regulasi dan kelemahan penegakan hukum.

Sedangkan berdasarkan penelitian yang dilakukan oleh penulis ada beberapa faktor yang mempengaruhi perlindungan konsumen dilihat dari kasusnya yaitu:

1) Keamanan mesin ATM

Pihak bank mengontrol mesin ATM secara berkala untuk memastikan bahwa mesin ATM yang akan digunakan oleh para nasabah dalam keadaan baik dan aman. Minimnya upaya pengawasan bank terhadap mesin ATM dan mesin EDC.Tidak terdapat hal-hal yang merugikan nasabah misalnya alat skimmer.

2) Sistem Keamanan bank

Pada sistem keamanan bank diperkuat kembali dengan memperbaharui sistem dengan yang lebih update lagi sesuai dengan perkembangan zaman.

3) Pemasangan CCTV di tempat yang terdapat mesin ATM 
Untuk memantau situasi ditempat pengambilan uang melalui ATM maka dibutuhkan CCTV. Hal ini sangat berguna sekali dimana bank dapat melihat kegiatan yang dilakukan oleh nasabah atau masyarakat yang masuk ketempat tersebut. Jika terjadi sesuatu yang mencurigakan bank dapat mengetahuinya melalui CCTV. Seperti halnya dalam kasus card skimming pelaku kejahatan terlihat dikamera satu orang pelaku mengambil uang dengan beberapa rekening yang berbeda ditempat yang sama. Atau dapat juga terlihat dalam satu nomor rekening yang sama dapat dilacak diambil oleh beberapa orang yang berbeda dalam jangka waktu beberapa hari ditempat yang berbeda sedangkan pemilik rekening berada ditempat yang berbeda pula dari pelaku yang mengambil uangnya.

4) Menggunakan Personal Identification Number (PIN)

Sebelum menggunakan PIN, pastikan tutup kanopi papan ketik tidak dipasang kamera tersembunyi. Dalam menekan PIN ketika menggunakan mesin ATM, harus menutupi jari nasabah ketika nasabah. Ketika skimmer mendapatkan PIN nasabah, maka dana nasabah akan terancam diambil oleh skimmer dengan menggunakan ATM duplikat yang dibuatnya.

5) Menggunakan token

Token adalah alat untuk authentikasi terhadap user ketika ingin masuk kedalam sistem (Rizki Wicaksono: ilmuhacking.com: 2009). Alat kecil ini bekerja ketika nasabah menggunakan kartu ATMnya untuk bertransaksi dengan tujuan untuk membuktikan siapa yang bertransaksi menggunakan kartu nasabah apakah nasabah itu sendiri yang menggunakan kartunya atau orang lain. Dalam menggunakan token juga membutuhkan PIN yang hanya diketahui oleh pemilik token tersebut. PIN yang dipakai untuk mengauthentikasi transaksi yang masuk pada rekening nasabah hanya digunakan sekali saja setelah itu digantikan dengan PIN yang baru. Hal ini sangat menyulitkan bagi pelaku skimmer untuk mengambil uang nasabah. 
6) Batasan pengambilan uang di mesin ATM

Dalam pengambilan uang di mesin ATM, BNI Syariah membatasi jumlah pengambilannya. Hal ini dilakukan untuk keamanan pemegang kartu ATM serta mencegah agar pihak lain yang mengambil dana nasabah tanpa seizin nasabah dapat dibatasi, dan tidak dapat mengambil semua.

7) Lingkungan sekitar

Lingkungan sekitar tempat pengambilan uang melalui ATM juga sangat berpengaruh terhadap perlindungan nasabah. Jika ingin mengambil uang melalui ATM, nasabah harus memperhatikan lingkungan sekeliling tempat dimana ATM tersebut berada. Selain itu berhati-hatilah kepada orang yang mengantri di belakang nasabah, bisa jadi dia adalah seseorang yang ingin mengetahui PIN pribadi nasabah dengan maksud yang tidak baik.

8) Data nasabah pada Kartu ATM

Data nasabah yang tersimpan dalam magnetic stripe pada kartu ATM sewaktu-waktu dapat diambil oleh orang lain salah satunya dengan menggunakan alat yang bernama skimmer. Oleh karena itu harus waspada jika ingin mengambil uang dengan menggunakan ATM. Perhatikan mesin ATM dengan seksama jika ada yang mencurigakan dari mesin tersebut jangan memasukkan ATM pada mesin ATM tersebut. Bank Indonesia sudah mengeluarkan perintah untuk mengganti magnetic stripe dengan menggunakan chip. Hal ini diharapkan agar data nasabah dapat lenih terlindungi.

9) Edukasi terhadap nasabah Dalam hal melindungi nasabah dari pelaku kejahatan, maka nasabah berhak mendapatkan edukasi dari bank tentang setiap informasi yang terjadi yang berhubungan dengan hak dan kewajiban nasabah.

10) Nasabah sebagai konsumen

Nasabah sebagai pengguna kartu ATM harus lebih berhati-hati dalam menggunakan ATMnya, 


\section{Faktor-faktor yang mempengaruhi perlindungan hukum dilihat dari Undang-Undangnya}

Faktor yang mempengaruhi perlindungan nasabah dilihat dari undangundangnya serta ketentuan perjanjian yang mengatur hubungan antara bank dan nasabah. Hubungan hukum antara bank dan nasabah yang terbentuk dari perjanjian harus dibuat dengan memperhatikan kedua belah pihak yaitu nasabah dan bank.

Rutten dalam Purwahid Patrik yang menyatakan bahwa perjanjian adalah perbuatan yang terjadi sesuai dengan formalitas-formalitas dari peraturan hukum yang ada tergantung dari persesuaian kehendak dua atau lebih orang-orang yang ditujukan untuk timbulnya akibat hukum dari kepentingan salah satu pihak atas beban pihak lain atau demi kepentingan masing-masing pihak secara timbal balik (Patrik, 1988:1-3).

Perjanjian yang dilakukan antara bank dan nasabah sudah ditetapkan dengan perjanjian baku yang seringkali memihak kepada bank sedangkan nasabah hanya bisa menerima perjanjian tersebut.

Dengan adanya perjanjian baku yang ditetapkan pihak bank yang seringkali merugikan nasabah, maka dibutuhkan suatu undang-undang yang melindungi kepentingan nasabah. Faktor terbentuknya Undang-Undang Perlindungan Konsumen diharapkan menangkis dan menggagalkan perjanjian yang dibuat antara bank dan nasabah diantaranya yaitu pengalihan tanggungjawab pelaku usaha yaitu bank yang merugikan nasabahnya. Sehingga tercipta keseimbangan antara bank dan nasabah dalam bertransaksi.

Faktor aparat penegak hukum juga berpengaruh dalam melindungi nasabah dalam bertransaksi menggunakan ATM. Para penegak hukum diharapkan dapat menjalankan tugasnya sesuai dengan peraturan perundang-undangan yang berlaku dan tidak memihak pada satu kepentingan saja. Serta dapat membuat Undang-undang perlindungan 
terhadap nasabah lebih akurat lagi sehingga tercipta adanya keseimbangan, ketenangan, ketentraman, kedamaian antara bank dan nasabah.

Nasabah harus diberikan edukasi tentang adanya perlidungan hukum yang diberikan agar mereka mengetahui bahwa hak-hak mereka dilindungi. Sehingga nasabah tidak begitu saja membiarkan hak mereka diambil oleh pihak lain.

\section{Penutup}

\section{A. Kesimpulan}

1. Penerapan pelaksanakan pertanggungjawaban BNI Syariah Pusat di Jakarta terhadap nasabah yang terkena kasus card skimming sudah sesuai dengan Undang-Undang Nomor 8 Tahun 1999 Tentang Perlindungan Konsumen. Setelah melakukan penyelidikan dan benar terbukti bahwa nasabahnya tersebut terkena skimming maka BNI Syariah mengganti kerugian yang diderita oleh nasabah sepenuhnya sebesar $100 \%$ atau sesuai dengan besarnya kerugian yang diderita nasabahnya dan menjamin bahwa tidak akan terjadi kembali kerugian yang dialaminya. Selama penggantian yang dilakukan terhadap kerugian yang diderita oleh nasabahnya, BNI Syariah belum pernah menerima laporan adanya ketidak puasan yang diderita oleh nasabahnya. Beban pembuktian atas kebenaran kasus yang dialami oleh nasabah merupakan tanggung jawab pelaku usaha hal ini diatur dalam Pasal 22 Undang-Undang Nomor 8 Tahun 1999 Tentang Perlindungan Konsumen.

2. Faktor-faktor yang mempengaruhi perlindungan konsumen dapat berasal dari nasabah itu sendiri, sistem yang diterapkan oleh perbankan, lingkungan, para penegak hukum, serta perjanjian yang dibuat antara nasabah dan bank faktor hukumnya, faktor sarana, faktor masyarakat 


\section{B. Saran}

1. Bank segera merubah tempat tersimpannya data dari magnetic tape menjadi chip seperti yang diperintahkan oleh Bank Indonesia.

2. Bank sebagai pelaku usaha harus memperkuat sistem perbankan dengan sistem yang lebih akurat sesuai dengan perkembangan zaman saat sekarang ini dimana banyak sekali kasus-kasus yang terjadi di bidang elektronik yang membahayakan bagi nasabah. Dan pada papan ketik mesin ATM dilengkapi dengan alat sensor cap jari yang terhubung dengan nomor rekening nasabah sehingga dapat langsung terdeteksi pengguna rekening nasabah bank.

3. Undang-Undang perlindungan konsumen diperbaharui kembali sesuai dengan perkembangan zaman. Dibutuhkan adanya peraturan yang mengatur tindakan yang harus dilakukan oleh bank dalam menindaklanjuti kejadian yang aneh dalam transaksi antara nasabah dengan perbankan harus menunggu laporan dari nasabah terlebih dahulu. Dalam Pasal 19 ayat (1) dijelaskan “...kerugian konsumen akibat mengkonsumsi barang dan/atau jasa yang dihasilkan atau diperdagangkan. Kalimat tersebut tidak dijelaskan mengenai tanggung jawab karena kesalahan atau kelalaian seseorang. Sebaiknya agar dapat diperjelas tentang tanggung jawab tersebut.

\section{Daftar Pustaka}

Sudaryatmo, Hukum dan Advokasi Konsumen, Bandung: PT. Citra Aditya Bakti, 1999

Syazali Husni dan Heni Sri Ismiyati, Hukum Perlindungan Konsumen, Bandung: Mandar Maju, 2000.

Adhi Maulana, "Begini Cara Kerja <i $>$ Skimming $</$ i $>$ Kartu ATM", tersedia di http://tekno.liputan6.com/read/2049670/begini-cara-kerja-iskimmingikartu-atm, (14 Mei 2019, 12:02 WIB.)

Satjipto Rahardjo, "Sisi-Sisi Lain Dari Hukum Di Indonesia”, (Jakarta: Kompas, 2003), hlm. 121.

Nasution AZ. Hukum Perlindungan Konsumen: Suatu Pengantar, Cet. Ke1, Jakarta: Diadit Meida, 2002. 
Rizki Wicaksono, "Memahami Cara Kerja Token Internet Banking”, tersedia di http://www.ilmuhacking.com/web-security/memahami-cara-kerja-tokeninternet-banking/, (27 Juli 2019)

Siadari Eben Ezer, BI: Ada Lima Titik Rawan Kejahatan E-Banking, 05 Juli 2012, 11:44 WIB,

http://www.jaringnews.com/ekonomi/perbankan/18179/bi-ada-lima-titik-rawankejahatan-e-banking. 